\title{
IRONÍA EN LA ESCRITURA MEMORIALÍSTICA DE TERENCI MOIX (EL CINE DE LOS SÁBADOS, EL BESO DE PETER PAN Y EXTRAÑO EN EL PARAÍSO)
}

THOMAS Fone

fonethomas@yahoo.es

RESUMEN

Este artículo consiste en analizar la ironía de la que Terenci Moix recurre para construir una imagen personal en sus memorias. Bastante significativo el uso reiterado de esta figura del lenguaje en su escritura, ya que, al tratarse de un mitómano bajo inspiración romántica, le permite focalizar libremente la atención en algunos temas claves que configuran la sociedad para interpretar irónicamente la condición humana; se burla de todo y de todos, mucho de sí mismo, llegando a caricaturizar el mundo con la intención de ver germinar otro nuevo, acarreador de nuevos valores.

Palabras clave: Ironía, memorias, Terenci Moix, condición humana, mundo.

ABSTRACT

This article is to analyze the irony of that Terenci Moix used to build a personal image in their memories. Quite significant is the repeated use of figure of speech in his writing, because, being a pathological liar in romantic inspiration, freely allows you to focus attention on some key issues that shape society to interpret the human condition ironically, mocks everything and everyone, a lot of himself, coming to caricature the world with the intention of seeing sprout a new one carrier of new values

KEYwoRDS: Irony, memories, Terenci Moix, human condition, world. 
En el ámbito literario, muchos estudiosos se han ocupado de la ironía, llegando a la conclusión de que es un concepto problemático, confuso, tramposo y de difícil definición ${ }^{1}$. Sin embargo, Booth (1986: 18) explica que «es un término que puede representar una cualidad o don en quien habla o escribe, para algo que hay en la obra y para algo que acaece al lector o al oyente». Rotulada de manera seria para unos y frívola para otros, también viene a entenderse que esta figura estilística, empleada con frecuencia por Sócrates para descubrir a los sofistas, puede variar su interpretación según las culturas, dado que existe una amplia tipología de tratamiento irónico: la socrática ${ }^{2}$, la cómica ${ }^{3}$, la romana $^{4}$, la verbal ${ }^{5}$ y la trágica o dramática ${ }^{6}$. Así pues, entendida como fenómeno comunicativo, la ironía significa sutileza y complejidad discursiva, que aparece bajo muchas formas. Aplicable a determinadas disciplinas científicas ${ }^{7}$ y a realidades heterogéneas, su ámbito semántico corresponde al nivel connotativo ${ }^{8}$. Podría desempeñar una función referencial y conativa. En cuanto a la función referencial cuyo papel consiste en remitir a un referente, resulta importante la situación o el contexto social como elemento de mayor relieve o factor determinante ${ }^{9}$, al que se refiere el mensaje. De esta forma, se resaltan el valor o el componente ilocutivo de la ironía para denunciar o ridiculizar algo o burlarse de alguien; se conceden un papel al destinatario, es decir, que al valor semántico, se le suma el pragmático.

En los años sesenta, la teoría de los actos de habla (Austin, 1962) establece tres dimensiones del acto lingüístico, de las cuales el acto ilocutivo resulta el que más conviene al estudio de la ironía, tal como subraya Kerbrat-Orecchioni coincidiendo con Gioia (2005), dado que persigue la meta clara de atacar o combatir a una víctima. Es en este sentido en el que cobran fuerza las reflexiones de Fernández Prieto (2004: 100) y de Mueke (Tapia , 2007), cuando centra el objetivo de la ironía en «una persona (incluyendo al propio ironista), una actitud, una creencia, una costumbre social, una institución, un sistema filosófico, una religión, una forma de civilización o la vida misma» ${ }^{10}$. La acción irónica domina el discurso de Terenci Moix, incidiendo en todos estos aspectos, aplicando una mirada irónica tanto al yo como al otro y al sistema de valores que domina el entorno. En su apuesta por reivindicar el valor de la integridad, por encima de otros intereses sociales, procuraremos poner de manifiesto que el tono irónico, mediante los di-

\footnotetext{
${ }^{1}$ El caso de De Man (1996), apoyándose en los románticos Schlegel, Hegel y Kierkegaard, merece señalarse, a pesar de dar como título a su conferencia El concepto de la ironía.

${ }^{2}$ Es la utilizada por Sócrates en su método dialéctico.

${ }^{3}$ Se trata de una congruencia aguda entre nuestras expectativas de un suceso y lo que ocurre.

${ }^{4}$ Es la usada en la Roma Antigua en los discursos y conversaciones retóricas públicas con palabras opuestas a su significado o intención.

${ }^{5}$ Es el uso de palabras para referirse a algo que es más, y normalmente, lo opuesto al significado literal de las palabras. Asimismo, Booth (1986: 26) distingue las ironías cósmicas, las ironías de destino y las ironías de acontecimiento. Por su parte, Haverkate (Torres Sánchez, 1999: 1-2) distingue la ironía del sino, la ironía verbal y la ironía dramática. Podrían multiplicarse los ejemplos.

${ }^{6}$ Empleada en la Antigua Grecia, es un recurso para aumentar la intensidad de la situación.

${ }^{7}$ Son entre otras la filosofía, la lingüística, la psicología, el cine y la literatura, etc.

${ }^{8}$ Cf. Ramírez (1992), Torres Sánchez (1999), Gioia (2005), Fernández Prieto (2004), Armendáriz Armendáriz (2005), etc.

${ }^{9}$ Así lo entienden Brooks (Torres Sánchez, 1999: 11) y Sperber y Wilson (1986) desde la Teoría de la Relevancia.

${ }^{10}$ cf. también Booth (1986: 187) y Mueke (Torres Sánchez, 1999: 19).
} 
ferentes recursos lingüísticos y pragmáticos, es el instrumento más eficaz en unas memorias destinadas a reafirmar su personalidad y luchar por las propias convicciones.

\section{Marcas Textuales: Diálogo, Metáfora, Paradoja, Ironía Verbal, Retrato, Descripción, Vulgarismos, Autoalusiones, Preguntas Retóricas}

En el empeño de dar cuenta de su balance vital, dotarlo de sentido y mirar con esperanza hacia el futuro, Terenci Moix favorece la ironía en sus memorias para denunciar los peores aspectos de la sociedad y de la especie humana. Organiza su discurso en una textualidad, recurriendo fundamentalmente al diálogo entre los personajes, en el que cabe especificar otras figuras de pensamiento.

Mediante el diálogo, en forma más o menos teatral, hace valer la ironía para desenmascarar a los curas durante la Semana Santa, ya que erigiéndose en autoridad moral, clasifican las películas entre buenas y malas, dedicando su tiempo a imponer el formato y el contenido de aquellas que tienen que ver los niños para su buena salud espiritual. Sin embargo, Ramón, como adolescente con un carácter desafiante, se atreve viendo una película laica en una sala alborotada de gente, hecho en el que se apoya para ironizar sobre la censura de los curas, evidente en la conversación que mantiene con el padre David diciéndole:-Pues el cine estaba bien lleno. Y muchos de pie y todo (Moix, 1998a: 311). En este caso, estaríamos ante la entendida respectivamente por Jankelevitch y Reyes (Torres Sánchez: 110-112) como la ironía cerrada y la ironía de poder; y que contrae la destrucción y la subversión por remover valores y creencias tradicionalmente consolidadas en la cultura cristiana. Así pues, como arma ofensivo, la usa para cuestionar el valor de la religión católica que pretende moldear el comportamiento y la vida de los hombres, imponer su fe ante los intereses particulares, en un mundo cada vez más individualista. El escritor critica duramente y muchas veces de manera vísceral la hipocresía de la Iglesia Católica ejemplificando sobre su efecto nocivo en la propia formación tratando de inculcarle una moral adversa a la amistad, los valores de amor y la libertad intelectual.

Como figura de pensamiento, la ironía funciona en la medida en que el receptor comparte las creencias del emisor sobre el objeto ironizado. Durante siglos, la Retórica se ha ocupado de este arte de elegancia y convencimiento que establece la ironía por su importancia en el intercambio comunicativo y su capacidad de permitir que se realice el ajuste entre el pensamiento y la audiencia, tesis que daría lugar a las teorías interpretativas pragmáticas. Desde esta perspectiva, requiere de una víctima y de un decodificador que colabore en la resolución de la incongruencia del enunciado. De ahí que se pueda hablar de la interdependencia entre ironía y víctima, tal como explica Mueke (Tapia, 2007) cuando apunta que la «típica víctima de una situación irónica es fundamentalmente un inocente, de modo que la ironía de la mayoría de las situaciones irónicas es que éstas no pueden existir sin alazon o charlatán complementario» ${ }^{11}$. En esta línea, De Man (1996: 2) recuerda que en Grecia o en la comedia helénica, muchos discursos se organizan en torno a la tradicional oposición entre eiron (chico listo) y alazon (chico tonto o ciego). El

\footnotetext{
${ }^{11}$ Vladimir Jankélévitch (P. Ballart, 2003) se sitúa en la misma dirección.
} 
«chico listo, que es por necesidad el que habla, siempre resulta ser el chico tonto, y que siempre es encuadrado en el papel de chico tonto, el alazon».

Podría ilustrar esta tesis el episodio con el cura que le prohibió la lectura de Sinuhé, el egipcio, alegando su peligroso contenido para la salud espiritual del niño Ramón y al que éste silencia recordándole la inmoralidad de espiarles casi desnudos en clases de gimnasia: - ¿Es que no estamos los niños casi desnudos cuando usted viene a espiarnos en las clases de gimnasia? (Moix, 1998a: 361). La acusación le valdrá para recuperar el libro, su capa de cruzado y lograr que le permita cantar en el coro. Desde temprano, el niño comprende y maneja las fórmulas del simulador y los efectos de la impostura, dejando atrás su propia voz en beneficio de una nueva que es irónica. Es ésta una estrategia que valida la ironía desde la Teoría de la Pretensión o del Fingimiento, tal como entienden Clark y Gerrig (Torres Sánchez, 1999). Contra dicha censura del cura, se alza la madre de Ramón. Mediante los signos de comicidad, que aparecen, por ejemplo, en sus gestos, la mirada, la sonrisa o el cambio de tono en la voz, pone en evidencia a este sacerdote, con el siguiente argumento: ¿No dicen que al niño le conviene leer? Pues bien que lea (Moix, 1998a: 358-359) ${ }^{12}$.

Si bien en la escritura moixiana el diálogo se contempla como una herramienta al servicio de la ironía, lo cierto es que la intención de este relato se enmarca en uno de los objetivos fundamentales de su discurso, evidenciar los oscuros fondos de sujetos eclesiásticos dedicados a la formación de menores, dando fe de la experiencia ineludible que justifica su animadversión. Relata Moix, recurriendo a la paradoja, como todo ello ocurre tras previa relación sexual con el educador, como puede apreciarse en la siguiente referencia textual, donde la interdicción irónica recurre a lo que Mueke (Armendáriz Armendáriz, 2005) denominaría ironía situacional o ironía de destino:

Yo hice lo que me pedía, aunque si bien se mira no era demasiado, pobre hombre: una simple felacio ejecutada por labios inexpertos. Al parecer, quedó satisfecho de mis servicios pero, una vez sereno, me recomendó que no contase nada a nadie, pues él podría acusarme de haberle robado cualquier cosa y no sólo me echarían de la escuela sino que, además, iría a un reformatorio como el que encerraron al pobre Tom Brown en sus días escolares (Moix, 1998a: 365).

La denuncia de esa doble moral, que parece más escandalosa cuando toca a la sexualidad, constituye una piedra angular de la hipocresía atribuida a la Iglesia, pero no por responder a esquemas de comportamientos repetidos y conocidos, deja el autorretrato de Moix de tener valor testimonial. Si bien, responde igualmente a intereses de exhibición personal, lo que agudiza la actitud irónica y los elementos de comicidad, como sucede con el episodio de la confesión, cuando el cura pregunta muchas veces al niño si se siente responsable de actos impuros. Ante su negativa, se produce un silencio, zanjado con la absolución y la salida del confesionario (Moix, 1998a: 367-368).

En las memorias, Ramón se presenta como un adolescente entristecido por falta de pareja sentimental estable. Así pues, si uno se fija en el consuelo que le da su amigo Ro-

\footnotetext{
${ }^{12}$ Los rasgos emocionales y expresivos que inciden en su actitud ironista son reconocidos por estudiosos que contemplan la ironía desde un punto de vista lingüístico. Son entre otros el lexicógrafo Casares (1969), Frubetzkoy (1973), Jakobson y Halle (1973), Weinrich (1966), Froser (1979), Fónagy (1971), Schaeffer (1981), Kerbrat-Orecchioni (1980) (Torres Sánchez, 1999: 33-37).
} 
berto, diciéndole que tiene una madre adorable, tras verle hundido por muchas decepciones amorosas, éste le replica: «Todos los que me habéis hecho daño sois maravillosos y me queréis bien. Espero que siga siendo así durante el resto de mi vida. No podría soportar que me hiciera daño alguien que no me quisiera» (Moix, 1998b: 562). De manera mucho más evidente, la ruptura sentimental con el adolescente Daniel le provocó una inquietud espiritual aguda, y, en boca de aquel amigo al verle muy apenado, pone las siguientes palabras: Eres un amante perfecto (Moix, 1998c: 563). En estos dos casos, el escritor recurre a la antífrasis, o lo que podría denominarse carientismo o metáfora, tropo al servicio de la ironía, para poner al descubierto el engaño del hombre. En ambos ejemplos, donde se pone de manifiesto el espíritu burlón de la ironía, potenciado por los adjetivos maravillosos, perfecto y el adverbio bien, se ve claramente cómo Ramón hace unas declaraciones argumentando de manera indirecta para decir lo contrario, por lo que se burla de los responsables del daño psicológico y moral sufrido. Son, en definitiva, en su inmensa mayoría, todos aquellos con los que quería intimar, aunque su deseo se viera frustrado por el rechazo, no quedándole más remedio que desdoblarse en la ironía verbal, con la intención de iluminar la maldad y el cinismo que caracterizan a la especie humana.

Pues bien, burlarse de sus contrincantes, como se aprecia en Ramón cuando señala a sus amigos, equivaldría a denigrarles, desvalorizarles o ridiculizarles; sería una alabanza simulada para atacarles. En cualquier caso, como la inversión del sentido que caracteriza a la ironía se da partiendo de lo positivo a lo negativo, opina Kerbrat (1986) que se critica «como si se alabase, se describe en términos valorizantes una realidad que se quiere desvalorizar». Se trataría, en palabras de Debyser (1980), de un insulto afectuoso, o del agradecimiento en forma de insulto. En este sentido, Freud ve en la ironía «una variedad de lo cómico que se parece al chiste por la utilización consciente de una técnica común al chiste y al sueño, la representación indirecta por lo contrario» (Gioia, 2005). En fin, sobre la base de los dos ejemplos señalados más arriba, cabe hablar -subraya Kerbrat-Orecchioni (Gioia, 2005) - de la ironía no citacional en la que Moix se refiere a una situación irónica y la citacional donde como víctima, se perfila como un enunciador citado, respectivamente.

Ramón se identifica en la escritura terenciana como un adolescente de trato fácil, muy dado a la amistad. De este modo, la estructura conversacional tiene también que ver con la carta que ha recibido de su amiga americana Mary Martín, con un español poco elaborado, motivo de ironía verbal por parte de sus familiares. Si uno se fija exclusivamente en la única reacción de su madre, se observa cómo con un tono despectivo, sentencia: ¡Que no practique tanto, que la harán miembro de la Real Academia! (Moix, 1998b: 111).

De las cinco circunstancias -ignorancia, incapacidad de prestar atención, prejuicios, falta de práctica e inadecuación emocional- propuestas por Booth (1986: 281-287), por las que un hombre puede ser víctima de la ironía, la tercera y la quinta son las que aquí convienen al niño Ramón por reflejar los estragos sufridos por el mero hecho de ser homosexual; ahora bien, como escritor, la primera y la cuarta (ignorancia y falta de practica) son empleadas por él sobre los personajes adolescentes, por ejemplo, cuando se burla de sus compañeros que no comprenden qué quiere decir con que ha intimado con el cura para conseguir ciertos privilegios, comentando en relación a la perplejidad ignorante 
de su burgués interlocutor: Y él no lo entendía. ¡Pobre, pobre Niño Rico! (Moix, 1998a: 366). De este modo, no cabe duda de que Moix

lleva a cabo una escenificación, se desdobla en un hablante ingenuo, el que emite en serio el enunciado, y en un hablante irónico, que le valora como absurdo, estúpido, banal, en suma incompatible con sus puntos de vista o con la realidad objetiva. Por eso el enunciador irónico es polifónico, pues en él se superponen dos voces, una ingenua, directa, superficial y audible; otra no ingenua, subterránea, burlona, descalificadora de la primera (Fernández Prieto, 2004: 103-104).

Hasta aquí, se hace evidente cómo Moix construye diálogos entre los diferentes personajes, como ocurre en el teatro, para burlarse de la gente e ironizar sobre actitudes y creencias. Desde esta perspectiva, cabe hablar de memorias dialogadas o dramáticas ${ }^{13}$.

Pero también en su escritura, hay enunciados reconocidos como irónicos desde un punto de vista pragmático. Así pues, frente a la intolerancia, la estrechez intelectual y la hipocresía moral, orienta su actitud irónica hacia su entorno familiar, visible en el lenguaje utilizado para nombrar la homosexualidad y la mentalidad de una madre que le lleva al médico para curarle de la misma:

No pensaba poner nada de mi parte. Aquella entrevista fue un mero trámite, algo que debía soportar para tener contenta a mamá o, cuando menos, para que durmiese tranquila, en la certeza de haber probado todos los remedios posibles para la salvación de su hijo. Una vez asumido que esto no era posible, me dejaría en paz (Moix, 1998b: 528).

Cuando arremete contra su madre por empeñarse tanto en curarle de algo que, para él, es natural y saludable, bajo el trasfondo irónico, Moix critica los estereotipos sociales de la ignorancia y la intolerancia. En su apuesta por la defensa a ultranza de su identidad sexual, se burla de su madre llevando a la práctica relaciones homosexuales el Viernes Santo: «Mi santa madre está en la procesión del pueblo. A estas horas ya llegan a la ermita. ¡Si supiese que su hijo está pecando con un pervertido! ¡Mi santa madre! En un altar debería tenerla y en cambio la escupo, la profano [...]» (Moix, 1998b: 221).

Siempre en relación con la homosexualidad, habitualmente, la intolerancia funciona, sobre todo, cuando se trata de un homosexual pobre o de clase social inferior. Sin embargo, la consideración hacia tal colectivo cambia cuando el interesado tiene un gran poder adquisitivo o goza de un prestigio social, como en el caso del padrino de Ramón, dado que por ser rico y tener un buen trabajo, infundía respecto, de igual modo que su pareja, el médico Roberto. Sobre esta realidad social, ironiza el escritor con acritud:

Si hay algo capaz de derrotar a los prejuicios morales, tanto en Cataluña como Addis Abeba, este algo es el dinero. Como en casa de mi padrino el dinero entraba a espuertas -al parecer gracias a unos providenciales cargos de Aduanas- incluso las cuñadas más exigentes se vieron obligadas a tragar. A partir de entonces, lo que podía parecer una tara pasó a ser expresado mediante un eufemismo muy finolis (Moix, 1998a: 167).

\footnotetext{
${ }^{13}$ Recordemos que del 22 de noviembre al 9 de enero de 2005, Xavier Albertí, bajo la dramaturgia de Lluïsa Curillé, llevó a escena El cine de los sábados y El beso de Peter Pan en el Teatro Romeo de Barcelona. http://actualidad.terra.es/artículo/html/av220042.htm
} 
Como no podía ser de otra forma, con fines polémicos, Moix se esconde detrás de la ironía para distanciarse de los prejuicios que rodean la homosexualidad, conducta sexual castigada durante el franquismo. Por miedo a ser reconocido y sancionado, al presentarse como un adolescente demasiado interesado en mantener relaciones sexuales estuviese donde estuviese, se opone al servicio militar, al considerándolo un tema turbio y sin importancia: «¿Qué ciencia podía ofrecerme? Ninguna que pudiera servirme para el futuro, mucho menos para mis ensoñaciones. Nunca había entrado en ellas acción militar alguna» (Moix, 1998b: 390).

En cuanto a la masturbación que constituye, según el catecismo de la Iglesia Católica, una falta grave, un pecado mortal, un vicio solitario, esclavizante, un acto intrínseca y gravemente desordenado, por ser una práctica fuera de las relaciones conyugales normales, ironiza Moix, exhibiendo su condición de homosexual practicante, recordando cómo una mano masturba a Ramón en el cine Cervantes (Moix, 1998b: 124), cómo éste se dedica muy a menudo a la masturbación, a la que llega a definir como un deporte, para luego pedir disculpas (Moix, 1998b: 92-95). En todo caso, se trata de un perdón irónico, con el agravante de intimar con un hombre el Viernes Santo (Moix, 1998b: 220) o ejercer la prostitución durante su estancia en París, desembocando en «situaciones trágicas y cómicas en las que el principio y el final, la premisa y conclusión son incongruentes con lo que la lógica, la justicia o el sentido común harían esperar» (Ramírez,1992: 6).

Su burla sincroniza con la relación conflictiva entre sus familiares, destacando casos, como el de su padre y de la tía Florencia que viven bajo el mismo techo, tratándose de usted, pero sin el menor respeto mutuo, y poniéndose de acuerdo nada más que para incordiar a los demás (Moix, 1998a: 126). Es ésta una situación que llama poderosamente la atención del niño Ramón en la infancia, periodo que requiere mayor protección, de tal modo que a la hora de pasar a ser Terenci Moix, la recupera para burlarse de sus familiares ya muertos, por convertir, opina, su vida en un exilio permanente: «¿Cómo podéis pedirme ahora que os respete en la memoria, si no supisteis respetarme a mí?» (Moix, 1998a: 410).

Igualmente, con mordaz ironía, recuerda la escuela nacional católica de su tiempo, calificándola de infierno por oponerse, de manera radical, a sus intereses. Según sus palabras, es donde recibió los castigos físicos y las torturas mentales (Moix, 1998a: 371).

También, la ironía en el discurso de Moix conecta con el retrato que hace de algunos de los personajes. Como anticlerical, llama santurronas a las monjas (Moix, 1998a: 101). Con rencor por el maltrato, que dice haber recibido, califica de señoronas, rubias mal teñidas, vozarrón de cazalla a algunas pedagogas responsables de su formación en la infancia (Moix, 1998a: 201). Ajusta cuentas con el censor de sus dibujos con calificativos, tales como senecto con piel rojiza, nariz ganchuda, dientes de menos, espalda encorvada, etc. Tal burla encuentra una justificación por haber calificado de provocativos y pornográficos sus dibujos, entendiendo que Ramón incurre en una falta grave de oprobio e inverecundia. Como lo es propio, ironiza sobre el comportamiento del censor: «Qué no habría dicho, el botarate, si le hubiera contado mis experiencias en el Cine Cervantes y en el lavado de la imprenta?» (Moix, 1998b: 324). 
Asimismo, la descripción tiene que ver con la estructura irónica en el relato. Conviene destacar, por ejemplo, que Terenci Moix, como crítico social, describe con ironía lo que percibe en el trayecto Barcelona-Nonaspe o Barcelona-Madrid tras la guerra civil española. En relación con el primer caso, describe la miseria, incidiendo en las peores condiciones de viajes, evidentes en ferrocarriles «miserables, sucios, abarrotados, premiosos. Trastos, antiguallas, chatarra humeante, capaz de aprisionarnos más de ocho horas durante un trayecto de apenas doscientos kilómetros» (Moix, 1998a: 278).

De la misma manera, el vulgarismo figura como componente irónico en las memorias del escritor catalán. Ramón lo usa para ir en contra de los censores, que impiden a los menores, entre los cuales se encuentran asistir a los espectáculos, exclamando ; $L a$ puta madre que los parió! (Moix, 1998a: 173). La tía Florencia, por su parte, no constituye una excepción, dado que al referirse a la amiga de Ramón, que le ha enviado una carta llena de faltas de ortografía, ironiza: Esta mujer está lirona. No se le entiende ni pum ni pam (Moix, 1998b: 112). Del mismo modo, Ramón apoda Niño Sabio al adolescente Daniel, su ex pareja sentimental, por sus continuas artimañas para escaparse y no retomar la relación (Moix, 1998c: 590). Encuentra interesante favorecer el uso de ;collons! para burlarse del comportamiento del cura que le condena por haber pecado (Moix, 1998a: 312), de su padre (Moix, 1998a: 346) y del médico (Moix, 1998b: 174), ya que le ofenden por su orientación sexual. Como no podía ser de otra manera, con indignación, recuerda la expresión vulgar estereotipada maricón utilizada por muchos de los personajes para ironizar sobre su condición sexual.

Cuando menos, la dimensión estética de la ironía, entendida como juego y que Schlegel (De Man, 1996: 7-8) propone como primera manera de abordarla, se encuentra en la escritura moixiana, buscando una gran variedad de efectos literarios, configurando su imagen sobre la exhibición transgresora y la irreverencia. De este modo, sin miedo a ser demandado o sancionado, convierte sus memorias en un espacio idóneo para ajustar cuentas con la intransigencia de quien le ha perjudicado, excluido o criticado, en la medida en que su burla se traslada al mundo en el que tras ciertas experiencias extremas, tan sólo merece su desprecio. De ahí que se pueda hablar de la ironía como saber o discurso antropológico, situándose en la línea de Ramírez (1992), éste guiado por Vico y Nieztsche, entre otros. En definitiva, Moix activa la dimensión estética de la ironía para estructurar su discurso, nutrir la fantasía, los sueños y deseos, estimular la creación, dinamizar o ralentizar el ritmo del discurso, cohesionarlo y dotarlo de sentido.

Para Shlegel, la segunda forma de tratar la ironía es reducirla a una dialéctica del yo, neutralizarla como una estructura reflexiva, por tener algo que ver con las reflexiones emanadas de la conciencia. Dado que, la «ironía representa claramente la distancia misma dentro del yo, dentro de las que el yo se mira a sí mismo desde una cierta distancia. Ello configura estructuras reflexivas y la ironía puede ser descrita como un momento de una dialéctica del yo» (De Man, 1996: 8), ironiza Moix en mayor grado sobre su infancia, insistiendo en una carencia total de la misma, recordando, por ejemplo, su expulsión a los dos años de un colegio misionero, por lo que se compara a sí mismo a un monstruo (Moix, 1998a: 97-98). Justifica tal comportamiento atípico para su edad por forjarse muy temprano en la costumbre del taco. Sorprende al presentarse como un niño rebelde, embargado por la soledad, visitando curiosamente los prostíbulos a los seis años (Moix, 1998a: 136). Son hechos, sin duda, claves para comprender la evolución del personaje, 
explicar la polémica que siempre rodeó su vida, si se da por sentado que la infancia es el paraíso del hombre. En este sentido, apela a la autoalusión lamentándose: «Mírame lector, mírame cómo era, cómo fui durante años, en el trayecto hacia la ilusión. Mírame saltando por las calles, ante las regañinas de la Custodia. Disculpa mi atolondramiento. Piensa que estoy avanzando hacia el cine de los sábados» (Moix, 1998a: 92).

Igualmente, su formación en la adolescencia, la declaración y aceptación en público de su homosexualidad y, sobre todo, la falta de estabilidad emocional le incita a refugiarse en preguntas retóricas, -que pueden interpretarse como una especie de monólogo interior o lo que William James denomina «el fluir de la conciencia»-, burlándose de sí mismo: ¿Por qué ese adolescente se siente tan desamparado? (Moix, 1998b: 206). Añade, tras haber sufrido una crisis existencial aguda por el desamor: ¿Era amor de verdad lo que tanto me había hecho sufrir? (Moix, 19988: 540). A raíz de las autoalusiones y preguntas retóricas, en las que de manera tácita el narrador pide la compasión y comprensión del lector, Moix nos encamina hacia el sentimiento trágico de la vida, pero también es cierto que su palabra virtual, en vez de liquidar otras voces, las complementa, las revela en su especificidad y las desmarca de los valores absolutos y de las verdades canónicas, pero conservándolas en el tiempo y espacio de su funcionamiento. De ahí que se pueda hablar de la ironía como fenómeno argumentativo; y así lo analizan Anscombre y Ducrot (Torres Sánchez, 1999: 68-70) en Teoría de la argumentación ${ }^{14}$. En fin, Moix, al recapitular irónicamente su vida, basada en los recuerdos de infancia y de adolescencia, reflexiona o especula sobre ella, la comenta, argumenta o valora; la problematiza al someterla a la discusión y al juicio público, quedando abierta a la interpretación y la reinterpretación.

\section{REFERENTES HistóRICO-SOCIALES}

Las tres primeras entregas de memorias de Terenci Moix se contemplan como la expresión de un mundo concreto, el del propio escritor por constituir el mejor ambiente propicio en el que lleva a cabo sus fijaciones. Conllevan, por tanto, un considerable valor informativo y comunicativo sobre su propia identidad, basada en los recuerdos de infancia y adolescencia. Pero también plasman irónicamente los problemas que conoce España tras la contienda civil: la miseria, el subdesarrollo, el hambre, el estraperlo y sobre todo la dictadura, traduciéndose en la censura, la represión policial y la falta de libertad individual y colectiva. Es en este sentido en el que se ha de entender a Ferré, para quien en la escritura autobiográfica, la

ironía implica un proceso de desdoblamiento en el autor, durante el cual el yo se divide en un yo empírico e histórico, y en un yo lingüístico. En realidad, el don irónico se concreta cuando el primer yo del escritor, el yo formado por su experiencia en el mundo, toma conciencia de la existencia de ese segundo yo que lo constituye en signo, en materia de esa misma historia que está narrando. Esta experiencia de distanciamiento, de objetivación del yo histórico, es lo que

\footnotetext{
${ }^{14}$ Estos teóricos defienden que la ironía es una antifrasis no léxica, sino pragmática, lo que da pie a una contradicción por la ambigüedad respecto al valor argumentativo. El análisis de Booth (1986: 332) respondería a este enfeque.

${ }^{15}$ Cf. Ferré. http://www.ensayistas.org/antologia/XXA/ferre/
} 
permite al escritor observarse a sí mismo (así como también el mundo) desde un punto de vista irónico y, a fin de cuentas, liberado ${ }^{15}$.

En esta línea, la ironía puede entenderse como un escudo ofensivo y defensivo, al mismo tiempo, constituyendo en el discurso de Moix una coartada para encolerizarse, luego denunciar y, por fin, distanciarse de los prejuicios que rodean la homosexualidad, orientación sexual castigada con pena de cárcel en la España franquista. Apela a este componente psíquico e incluso psicológico de la ironía, para rebelarse, sobrevivir e intentar dominar la crítica situación, desembocando en lo que Nietzsche denominaría la voluntad de poder. Este autor entiende la ironía como burla o sátira, haciendo uso de ella para ir en contra del poder represivo y dictatorial de Franco, empeñado en borrar toda huella de homosexualidad. En su apuesta por una sociedad libre, sin prejuicios, en la que es posible hablar de una sexualidad plural y mucho más abierta, con una visión irónica, sentencia, en relación con aquélla situación:

Resulta irónico que en aquel yermo de represión moral conociese tal prosperidad la industria de la carne. Durante el franquismo la búsqueda homosexual era mucho más activa de lo que normalmente se piensa. Los bares funcionaban a local lleno. Y aunque alguien pudiera pretextar que se trataba de puntos de encuentro, se convertían directamente en lugares de trato. Se perseguía el vicio [...] pero no se impedía que el vicio prosperase. Era cierto que la policía podía entrar en un bar y llevarse a todo el mundo a la comisaría, pero afortunadamente sólo actuaba de vez en cuando (cuestión de propinas, decían los malintencionados). La permisividad, de tal modo obtenida, beneficiaba hasta a los menores, de manera harto contradictoria (Moix, 1998b: 216).

De todas maneras, todo apunta a la conquista de mayores libertades como principal alegato para burlarse de la clase dominante, presentando a España como un país en quiebra que necesita de manera urgente un cambio de mentalidades. Visión personal, evidentemente, que Terenci Moix proyecta en un contexto histórico de la vida socio-política de la España reciente, validando la tercera manera que propone Schlegel para abordar la ironía, es decir, relacionándola con la historia ${ }^{16}$.

En tal marco, resultan de interés las reflexiones de Batjín (1989), ya que su concepto de dialogismo concede gran relieve a la ironía, por constituir, junto a la parodia, la forma más evidente y la primera manifestación de la dialogía en la literatura. Para el teórico ruso, en las biografías y autobiografías antiguas, la ironía, la parodia y la risa se presentan como instrumentos de suma importancia para cuestionar el monolítico lenguaje oficial idóneo para la representación heroica, introducir la conciencia individual en los textos, de tal modo que «lo particular y lo privado (que no encuentran formas positivas de expresión) se visten con la forma de ironía y el humor» (Bajtín, 1989: 295). Su tesis avala la conquista de la voz propia asimilada frente a la palabra autoritaria, por lo que entiende que la dialogía está enraizada de manera profunda en la vida y la conciencia humanas. De este modo, el proceso de formación ideológica del individuo se desarrolla

\footnotetext{
${ }^{16}$ Es una opinión compartida por Hegel y Kierkegaard. Destacando esta idea, Paul de Man (1996: 8) subraya que «de un modo simétrico a la forma en que puede ser absorbida en una dialéctica del yo, la ironía se interpreta y se absorbe dentro de un modelo dialéctico de la historia, de una dialéctica de la historia».

${ }^{17}$ Así lo ven Vico, Nietzsche, Kierkegaard, Wittgenstein, Saussure y Ramírez entre otros, destacando su
} 
asimilando selectivamente sus propias palabras en conflicto con la palabra autoritaria, es decir, el poder que apoya el dogmatismo.

También la filosofía ha mantenido una relación privilegiada con la ironía, recurriendo de vez en cuando a ella en determinadas circunstancias. Pues bien, desde la perspectiva retórico-filosófica, la ironía, entendida como figura del lenguaje ${ }^{17}$, o lo que De Man (1996: 18) llama «permanente parábasis de la alegoría de los tropos», consiste en decir ocultando o bromeando ${ }^{18}$, dado que el locutor irónico intenta aislarse de los demás, despistarles, distanciarse de ellos, confundirles o causarles perplejidad al considerarse superior, tal como defienden algunos estudiosos ${ }^{19}$; eso es lo que confirma Kierkegaard (Figueroa Weintzman, 2004) cuando alega que una «ironía que sea de la mayoría no es ironía». Es ésta una tesis insostenible en las memorias de Terenci Moix.

Acusado de frivolidad por algunos críticos, la ironía ha supuesto, para este autor, la herramienta literaria contra el pensamiento dominante en una España con falta de libertad y compromiso. Por otro lado, precisamente, ha sido esa criticada frivolidad el vínculo más fuerte con un público receptivo que sintonizaba tanto con sus formas como con sus contenidos. De hecho, la ironía que envuelve sus memorias no requiere un gran nivel intelectual para ser percibida por el lector, lo que ha buscado el escritor barcelonés es la risa de sus seguidores, burlarse mutuamente, familiarizar o humanizar los comportamientos. Con su juego, propone un nuevo mundo con otros valores, yendo mucho más allá de la definición de Figueroa Weitzman (2004: 102) cuando, apoyándose en Kierkegaard, sostiene que el interés del ironista es exclusivamente «deleitarse en el placer que causa la libertad de jugar al hablar y de emitir comentarios que pueden ser interpretados de modos muy diversos ${ }^{20}$.

Así pues, por el lenguaje popular de la escritura moixiana, en la fase de reconstrucción de su vida dotándola de sentido, el lector o receptor irónico descodifica rápido la polifonía ${ }^{21}$. Es decir, que detecta la intención implícita del escritor aun perteneciendo a otra cultura o teniendo experiencias vitales diferentes. De este modo, silencia lo que Reyes (1984: 178) llama ironía abortada, pues en este nivel, no se cuestionan tanto la competencia semántica, sino más bien la pragmática, al entrar en juego el conocimiento de un sistema de valores, creencias, saberes y afectos de aquellos que actúan entre sí. Aunque unos puedan sorprenderse, todo apunta que Moix contempla la ironía desde la Teoría de la conversación de Grice $(1975)^{22}$.

carácter polifónico. En esta línea, se sitúan Ducrot (1980), Maingueneau (1986) y Berrendoner (1981) (Gioia, 2005).

${ }^{18}$ El romántico alemán Friedrich Schlegel discrepa alegando que la «ironía no es cosa de bromas» (Ballart, 2003: 12).

${ }^{19}$ A tal propósito, Figueroa Weintzman (2004: 94), que recoge las aportaciones de Andrew Croos (1995) y Kierkegaard (1980), escribe: «La superioridad de la ironía estriba en el hecho de que, si bien quiere que la entiendan, no quiere que se la comprenda literalmente; para ello disfruta del lenguaje metafísico, y desprecia al discurso que todo el mundo puede entender en el acto. Hay una cierta supresión de sí mismo».

${ }^{20}$ Cf. la Teoría polifónica de Ducrot (Torres Sánchez, 1999).

${ }^{21}$ En relación con el carácter polifónico de la ironía, ya que una lectura irónica está sujeta a múltiples contingencias, Torres Sánchez (1999: 20) recoge las aportaciones de De Man (1969), Culler (1975) y Jauss (1977).

${ }^{22}$ Dicha teoría preconiza interpretar la ironía apoyándose en las nociones de implicatura conversacional y eonvencional. Si bien la ironía implica conversacionalmente lo contrario de lo que se dice, Grice (1975) sostiene que el locutor tiene que ir al grano y hacer relevante su contribución (máxima de calidad); debe ser escueto y ordenado, lo que equivale que su enunciado tiene que ser claro, preciso y no ambiguo (máxima de modalidad). En 
La ironía, fuente permanente de inspiración para investigadores, escritores y lectores, ha sido objeto de críticas $^{23}$. No obstante, si bien se mira como pieza clave de la pedagogía socrática, lo cierto es que constituye lo sustancial en Terenci Moix, pues alcanza su máxima expresión en sus memorias, en las que como mitómano que recrea sin pudor anécdotas, favorece dicho recurso para involucrarse en la sociedad de su tiempo, golpeando conciencias con todo aquello que nadie ignora, pero que muchos se niegan a admitir, por lo que Ballart (2003: 17) sostiene que un «espíritu irónico será lo único que nos salve hasta en medio del infierno más terrible que nos toque habitar».

Que la crítica en su inmensa mayoría haya coincidido en considerar al escritor catalán provocador, escandaloso y polémico es un hecho innegable, dado que al recurrir a la ironía para vertebrar su discurso, hace de ella una inagotable fuente de placer por proporcionarle libertad sin límites para enfrentarse con brillantez a los escollos de la vida, sincerarse dando a conocer su verdad sobre sí mismo y sobre el mundo que le ha tocado vivir, a pesar que Lapp (Torres Sánchez, 1999), en Teoría de la simulación ampliada, ve al ironista insincero, simulador y mentiroso, debido a la ambigüedad que rodea el concepto. En cualquier caso, si se suma tanto la categoría ética como la estética, dos ramificaciones al servicio de esta figura de pensamiento, se ve cómo Moix la eleva a una categoría existencial, a una herramienta de peso para iluminar el camino hacia la verdad, teniendo en cuenta la imposibilidad de una vida genuinamente humana sin ella ${ }^{24}$.

Funcionando como terapia en la que se apoya para escaparse del aburrimiento, lo cierto es que le permite interpretar la vida en función de la relación que mantiene con su entorno, sacando a la luz verdades ocultas y recreando el drama humano mediante valores y creencias de algunos personajes. Igualmente, como colabora a una lectura plural de sus memorias, resulta un factor enriquecedor desde un punto de vista social. En esta línea, trabaja García Pavón (2000: 5), ya que llega a reivindicarla para hacer frente a los desafíos de la sociedad, del mismo modo que lo haría Paul de Man, en su ensayo Blindness and Insight ${ }^{25}$. Desempeña, por tanto, un papel de mayor relieve en la vida humana debido a su impresionante desarrollo en la postmodernidad y, en palabras de Booth (1986: 189), por su expansión imperialista justificada por la naturaleza de las cosas, de la literatura y del mundo moderno, tesis condensada en Fernández Prieto (2004: 102).

relación con su tesis, discrepa Bela Allemann (1970) al ver interesante la ironía porque mantiene la burla irónica (Gioia, 2005; Booth, 1986).

${ }^{23}$ Para Booth (1986: 78-79), se trata de un ejercicio intelectual que funda hechos y valores, obligando a construir jerarquías alternativas. Con su práctica, el hombre manifiesta cierta superioridad frente a los demás; crea juicios de valores, acusando a los demás de equivocación en sus planteamientos, presentimientos, creencias y valores. Otras voces críticas insisten que la ironía, por ser tropo o lenguaje, supone que el ironista se separa de sí mismo, se distancia de los demás; acusado de elitista, no se compromete con nadie ni con nada, ya que repudia toda actividad humana al no concederle ninguna importancia. Tal conducta le coloca en una situación precaria y le convierte en un hombre negativamente libre; así lo señala, por ejemplo, Kierkegaard en su tesis doctoral sobre la ironía (Figueroa Weitzman, 2004).

${ }^{24}$ Así lo ve Kierkegaard (2000: 77), opinando que «Así como la filosofía comienza con la duda, la vida digna de ser llamada humana comienza con la ironía».

\footnotetext{
${ }^{25}$ Ferré. http://www.ensayistas.org/antologia/XXA/ferre/

${ }^{26}$ Cf. Grice (Torres Sánchez, 1999).

${ }^{27}$ En tal marco, De la Peña (1993: 9) sostiene que Moix «es implacable consigo mismo: duro, irónico, ácido con los miembros de su familia, al tiempo que enternecedor con mucho de los descubrimientos que en esos
} 
En síntesis, Terenci Moix entiende que el mundo es esencialmente absurdo; por ello, partiendo de la máxima de calidad, de sinceridad que prescribe «no digas cosas de las que crees que son falsas $»^{26}$, proyecta una luz irónica sobre los esfuerzos humanos, a través de su peculiar historia personal no exenta de un interés social, histórico y universal. En sus memorias subversivas, la ironía se desarrolla y se revela en distintos niveles, con distintos grados de complejidad, conformando el elemento estructurador de su discurso. A través de esta forma de expresión, pensamiento o comportamiento, al que apela para disfrutar comunicando, armar conflictos dando a conocer su verdad de los hechos, como rebelde con causa en busca constante de mayores libertades, no solo se burla de todos y de todo, incluso de sí mismo, intentando preñar de sentido su propia existencia, sino también caricaturiza al mundo ${ }^{27}$; se trata de un mundo en el que interpreta irónicamente la condición humana, por lo que su ironía de la vida se entendería como una vida salpicada de ironía.

\section{REFERENCIAS BIBLIOGRÁFICAS}

ARMENDÁRIZ ARMENDÁRIZ, Clara Irene (2005): «La ironía y algo más», UPIICSA XIII, V, 37, p. 15.

Austin, John Langshaw (1962): How to do things with words, Ed. J. O. Urmson Oxford, Clarendon. BALLART, Pere (2003): «La ironía como (último recurso)», Quimera, 232-233, p. 12-18.

BATJín, Mijaíl (1989): Teoría y estética de la novela, Madrid, Taurus

Воотн, Wayne Clayson (1986): Retórica de la ironía (versión de Jesús Fernández Zulaica y Aurelio Martínez Benito), Madrid, Taurus.

De La PeÑA, Luis (1992): «Las fuentes del retorno. Terenci Moix y el Nilo como símbolo», El País (Libros, Babelia 16), 1 de febrero, p. 13.

De Man, Paul (1996): El concepto de ironía, Valencia, Ediciones Episteme, S. L. Eutopías 2a época, 8 Folleto 111.

FERnÁndez Prieto, Celia (2004): «La ironía literaria: distancias y desdoblamientos enunciativos», en Estudios lingüísticos y literarios 'in memorian' Eugenio Coseriu (1921-2002), María Luisa Calero Vaquera, Fernando Rivera Cárdenas (eds.), Universidad de Córdoba, Servicios de publicaciones, p. 97-118.

FERRE, Rosario (s/f): «De la ira a la ironía, o sobre cómo atemperar el acerco candente del discurso», http://www.ensayistas.org/antologia/XXA/ferre/

Figueroa WeItzman, Rodrigo (2004): «Kierkegaard y la ironía», Revista de Filosofía, 60, Universidad Andrés Bello, p. 93-107.

GARCíA PAVÓN, Rafael (2000): «Kierkegaard ante la esquizofrenia de la multitud», El Garabato, 12, p. 1-5.

GioIA, Diana (2005): «La ironía», http://www.mundoculturalhispano.com/spip/spip.php?article 1348

HERNÁNDEZ GonZÁLEZ, María Belén (1999): «El humor, la ironía y el cómico: códigos transgresores de lenguajes e ideologías», SIGNA, p. 217-232. 
KIERKEGAARD, Soren Aabye (2000): Sobre el concepto de ironía en constante referencia a Sócrates, Madrid, Trotta.

Morx, Terenci (1998a): El cine de los sábados, Barcelona, Planeta.

- (1998b): El beso de Peter Pan, Barcelona, Planeta.

- (1998c): Extraño en el paraíso, Barcelona, Planeta.

PESTARINI, Luis (s/f): «Robert Sheckley: la ironía silenciada», http://axxon.com.ar/rev/159/c-159ensayo.htm

RAMíREZ, José Luis (1992): La existencia de la ironía como ironía de la existencia. Scripta Vetera (edición electrónica, ponencia leída en el Seminario de Antropología de la Conducta), Universidad de Verano, San Roque, Cádiz, p. 1-22.

Reyes, Graciela (1984): Polifonía textual, Madrid, Gredos.

TAPIA, Alejandro (2007): «El árbol de la retórica. Teoría, análisis y crítica de la cultura y la comunicación a partir de la teoría retórica», http://elarboldelaretórica.blogspot.com/2007/04/la-ironia-y-sus-empleos.htm

TORRES SÁNCHEZ, María Ángeles (1999): Aproximación pragmática a la ironía verbal, Cádiz, Universidad de Cádiz. 